University of Nebraska - Lincoln

DigitalCommons@University of Nebraska - Lincoln

Publications, Agencies and Staff of the U.S.

Department of Commerce

U.S. Department of Commerce

2010

Predicting the occurrence of Atlantic bluefin tuna (Thunnus

thynnus) larvae in the northern Gulf of Mexico: building a

classification model from archival data

\author{
Barbara A. Muhling \\ NOAA/NMFS/SEFSC, Barbara.Muhling@noaa.gov \\ John T. Lamkin \\ NOAA/NMFS/SEFSC \\ Mitchell A. Roffer \\ Roffer's Ocean Fishing Forecasting Service, Inc.
}

Follow this and additional works at: https://digitalcommons.unl.edu/usdeptcommercepub

Part of the Environmental Sciences Commons

Muhling, Barbara A.; Lamkin, John T.; and Roffer, Mitchell A., "Predicting the occurrence of Atlantic bluefin tuna (Thunnus thynnus) larvae in the northern Gulf of Mexico: building a classification model from archival data" (2010). Publications, Agencies and Staff of the U.S. Department of Commerce. 295. https://digitalcommons.unl.edu/usdeptcommercepub/295

This Article is brought to you for free and open access by the U.S. Department of Commerce at DigitalCommons@University of Nebraska - Lincoln. It has been accepted for inclusion in Publications, Agencies and Staff of the U.S. Department of Commerce by an authorized administrator of DigitalCommons@University of Nebraska - Lincoln. 


\section{Predicting the occurrence of Atlantic bluefin tuna (Thunnus thynnus) larvae in the northern Gulf of Mexico: building a classification model from archival data}

\author{
BARBARA A. MUHLING, ${ }^{1, *}$ JOHN T. LAMKIN ${ }^{1}$ \\ AND MITCHELL A. ROFFER ${ }^{2}$ \\ ${ }^{1}$ NOAA/NMFS/SEFSC, 75 Virginia Beach Drive, Miami, FL \\ 33149, USA \\ ${ }^{2}$ Roffer's Ocean Fishing Forecasting Service, Inc., 60 Westover \\ Drive, West Melbourne, FL 32904, USA
}

\begin{abstract}
Although bluefin tuna are found throughout the Atlantic Ocean, spawning in the western Atlantic has been recorded predominantly in the Gulf of Mexico (GOM) in spring. Larval bluefin tuna abundances from the northern GOM are formulated into an index used to tune the adult stock assessment, and the variability of this index is currently high. This study investigated whether some of the variability in larval bluefin tuna abundances was related to environmental conditions, by defining associations between larval bluefin tuna catch locations, and a suite of environmental variables. We hypothesized that certain habitat types, as defined by environmental variables, would be more likely to contain bluefin tuna larvae. Favorable habitat for bluefin tuna larvae was defined using a classification tree approach. Habitat within the Loop Current was generally less favorable, as were warmcore rings, and cooler waters on the continental shelf. The location and size of favorable habitat was highly variable among years, which was reflected in the locations of larval bluefin tuna catches. The model successfully placed bluefin tuna larvae in favorable habitat with nearly $90 \%$ accuracy, but many negative stations were also located within theoretically favorable habitat. The probability of collecting larval bluefin tuna in favorable habitat was nearly twice the probability of collecting bluefin tuna larvae across all habitats ( 35.5 versus $21.0 \%$ ). This model is a useful addition to knowledge of larval bluefin tuna distribu-
\end{abstract}

*Correspondence. e-mail: Barbara.Muhling@noaa.gov Received 9 November 2009

Revised version accepted 9 August 2010 tions; however, the incorporation of variables describing finer-scale features, such as thermal fronts, may significantly improve the model's predictive power.

Key words: bluefin tuna, Gulf of Mexico, habitat modeling

\section{INTRODUCTION}

Atlantic bluefin tuna (Thunnus thynnus; bluefin tuna hereafter) is a large and wide-ranging species, found throughout the Atlantic Ocean (Mather et al., 1995). Adult fish are highly migratory, and are capable of trans-Atlantic crossings (Restrepo, 1996; Block et al., 2001; Stokesbury et al., 2007; Dickhut et al., 2009). In the western North Atlantic, adult fish are found from cool-water foraging grounds in New England, to temperate coastal waters of the south-eastern US, and open ocean environments (Stokesbury et al., 2004; Block et al., 2005; Teo et al., 2007b). Spawning in the western North Atlantic has been recorded predominantly within the tropical waters of the Gulf of Mexico (GOM), in spring (April-June) (Richards, 1976; Scott et al., 1993). Tagging data suggest that not all sexually mature fish make this migration every year (Lutcavage et al., 1999; Block et al., 2001; Stokesbury et al., 2004), and it has been suggested that some spawning activity may take place elsewhere in the Atlantic (McGowan and Richards, 1989; Lutcavage et al., 1999; Rooker et al., 2007). Historically, bluefin tuna have been heavily exploited, and they are currently considered to be undergoing overfishing (McAllister and Carruthers, 2008). A steep decline in stocks was recorded in the 1970s, with stocks estimated to have stabilized at low levels since this time (Rooker et al., 2007).

Adult bluefin tuna can tolerate ambient temperatures from approximately 3 to $31^{\circ} \mathrm{C}$, which is the broadest thermal niche of any scombrid fish (Carey and Lawson, 1973; Block et al., 2001). Their unique physiology allows them to tolerate colder waters than tropical tunas, and to maintain their body 
temperatures above ambient water temperatures (Carey and Teal, 1966; Blank et al., 2004). However, this endothermic ability may present challenges for the fish in warmer waters, as when ambient temperatures exceed $30^{\circ} \mathrm{C}$, cardiac function in bluefin tuna is reduced (Blank et al., 2004). Surface water temperatures in the GOM during the spring spawning season regularly exceed $28-29^{\circ} \mathrm{C}$ (Muller-Karger et al., 1991; Zavala-Hidalgo et al., 2002), and data from electronic tags have shown water temperatures as high as $29.8^{\circ} \mathrm{C}$, with bluefin tuna body temperatures as high as $30.7^{\circ} \mathrm{C}$, within the GOM (Block et al., 2001, 2005). It has been proposed that the deep ( $>500 \mathrm{~m}$ depth) diving behavior shown by adult fish as they enter and exit the GOM may be to avoid heat stress from warmer waters (Teo et al., 2007b).

Although the GOM can be a physiologically stressful environment for adult bluefin tuna, they often migrate large distances to reach it (Block et al., 2001). It is likely that the adult fish are targeting specific habitats or oceanographic features in which to spawn, to maximize survival of larvae. Tagged adult bluefin tuna in the GOM have been shown to be preferentially located in lower continental slope waters, in areas with surface temperatures of approximately 24 $27^{\circ} \mathrm{C}$, and relatively low chlorophyll concentrations $\left(<0.16 \mathrm{mg} \mathrm{m}^{-3}\right.$ ) (Teo et al., 2007a). This type of behavior has also been seen in bluefin tuna in the Mediterranean Sea (Garcia et al., 2005; Alemany et al., 2010), and in other large pelagic species such as swordfish (Tserpes et al., 2008). The open GOM is warm, which would result in higher growth rates for larvae (Miyashita et al., 2000), and largely oligotrophic outside of river plumes (Muller-Karger et al., 1991; Gilbes et al., 1996), possibly providing an environment lower in planktonic predators. Diets of preflexion larval tunas tend to be specialized, focusing on particular items such as appendicularians, and many larval tunas are piscivorous post-flexion (Llopiz et al., 2010). These characteristics may represent a mechanism for larval survival in oligotrophic waters.

Physical and biological conditions for both larvae and adults in the GOM show high spatial and temporal variability, as a result of the dynamic oceanography of the GOM. The dominant feature is the Loop Current (LC), which enters the GOM through the Yucatan Channel in the south, extends northwards into the GOM, and then retroflects anti-cyclonically, exiting the GOM through the Straits of Florida (Fig. 1). The strength and degree of penetration of the LC into the GOM is highly variable, and not predictable on a seasonal basis (Sturges and Evans, 1983). On occasion, large, relatively warm eddies are shed
Figure 1. Locations of SEAMAP sampling stations for data used to construct the classification tree model. The probability of collecting at least one bluefin tuna larvae across all sampled years between 1982 and 2006 is shown, along with a schematic representation of the flow of the Loop Current.

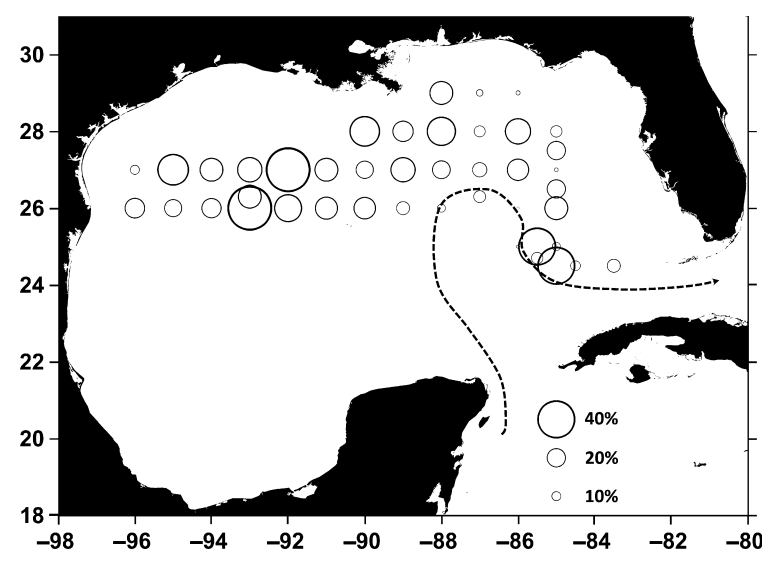

from the LC, which can persist for months to years as they drift into the western and southern GOM (Oey et al., 2005). Smaller cold-core eddies may also form, providing zones of local aggregation for zooplankton (Zimmerman and Biggs, 1999). Variability in the position and strength of these features is likely to drive the area, persistence and suitability of habitat favorable for larval bluefin tuna growth and survival, and thus recruitment to adult populations (Bailey et al., 1997; Hinrichsen et al., 2005). However, it is currently unknown which habitats within the GOM are more likely to contain bluefin tuna larvae.

Spring plankton surveys targeting larval bluefin tuna have been conducted across the United States Exclusive Economic Zone in the northern GOM since 1977. Larval abundances are formulated into an index, which is used to 'tune' or calibrate the adult stock assessments, which are completed through the International Commission for the Conservation of Atlantic Tunas (ICCAT) (Scott et al., 1993; Ingram et al., 2010). Larvae have been found across the northern GOM, with variable spatial and temporal distributions and high interannual variability, which has somewhat limited the usefulness of the index (Ingram et al., 2010). However, it is the only fishery-independent index used in the stock assessment. While it is likely that some of this variability has resulted from interannual variability in the oceanographic environment in the GOM, these influences have not been quantitatively evaluated.

This study aimed to construct a model which would define habitat most associated with larval bluefin tuna in the northern GOM, and determine whether larvae 
were found in a specific habitat envelope. We could then infer whether adult bluefin tuna spawning tended to target specific features or water masses. We hypothesized that certain habitat types, as defined by environmental variables, should be more likely to contain bluefin tuna larvae. A classification tree approach was employed to classify different habitats and conditions in the GOM in terms of their likelihood of containing bluefin tuna larvae.

\section{METHODS}

Larval bluefin tuna data were available for every year from 1982 through 2006, with the exception of 1985 and 2005, from the National Marine Fisheries Service Southeast Area Monitoring and Assessment (SEAMAP) Program. Both bongo and neuston net tows were completed across a grid of stations (the SEAMAP grid) in the northern GOM in late April and May, with sampling continuing into June in some years. Cruises were usually divided into two legs, with the grid of stations completed once on each leg. Bongo nets were fitted with $333-\mu \mathrm{m}$ mesh, on two $61-\mathrm{cm}$ diameter round frames, and were towed obliquely as described in Scott et al. (1993) and Richards et al. (1993), mostly to $200 \mathrm{~m}$ depth. Neuston nets were fitted with $0.95-\mathrm{mm}$ mesh on a $1 \times 2 \mathrm{~m}$ frame, and were towed at the surface. Samples from the neuston net, and the right bongo net only were sorted, and larvae identified to the lowest possible taxa at the Polish Plankton Sorting and Identification Center in Szczecin, Poland. The identifications of Scombridae larvae were validated at the Southeast Fisheries Science center in Miami, Florida, and occurrences of larval bluefin tuna were recorded. In all, 658 larvae from bongo net samples and 2222 larvae from neuston net samples were measured, using an eyepiece micrometer. Due to shrinkage inherent with preservation, and the high variability in age at length of small bluefin tuna larvae which have been aged in the Western Atlantic (Brothers et al., 1983), length data were not included in modeling analyses. Although there was considerable variability in the number of stations sampled, and the extent of the grid from year to year, stations at whole degree intervals at least were sampled in most years (Fig. 1).

The environmental variables selected for analysis were included for a variety of reasons. Temperature and salinity data delineated water masses, to test whether bluefin tuna avoid spawning in certain oceanographic features. Wind speeds, which affect mixed layer depth and stratification (Lasker, 1975), and settled plankton volumes provided variables re- lated to larval feeding. The time of day and moon phase were proxies for catchability, as some larval fish are caught in greater numbers at night, or when the night sky is darker, around the new moon (Hernandez and Shaw, 2003). Adult bluefin tuna have also been shown to exhibit behavioral differences with different moon phases (Wilson et al., 2005). Latitude, longitude and water depth were included to test whether certain geographical locations within the GOM were more likely to contain bluefin tuna larvae, regardless of environmental conditions, and day of the year was included to test for date-related increases in spawning activity.

Hydrographic data were collected using a Seabird SBE 9/11 Plus CTD with an SBE 03 temperature sensor, SBE digiquartz pressure sensor, SBE 04 conductivity sensor, and SBE 43 dissolved oxygen sensor (Bellevue, WA, USA). Temperature and salinity at the surface, at $100 \mathrm{~m}$ depth, and at $200 \mathrm{~m}$ depth were available for the majority of stations, although the availability of environmental data was more complete in some years than in others (Table 1). Standardized settled plankton volumes $\left(\mathrm{cm}^{3}\right.$ per $100 \mathrm{~m}^{3}$ seawater sampled) were calculated using the volume filtered data from the flowmeter fitted to the bongo net. Water depth data were inconsistently recorded over the survey period, and so station depth data were extracted from interpolated, 1-min bathymetry data from the British Oceanographic Data Centre. Interpolation was completed using kriging in SURFER 9 (Golden Software, Golden, CO, USA), and values for each station location were extracted using Spatial Analyst in ARCGIS 9.2 (Environmental Systems Research Institute, Redlands, CA, USA).

Temporal variability in sampling was also considered on three different scales. The day of the year (Julian day) was included as a continuous variable, and the time of day that sampling took place was represented as a four-digit variable (e.g., 23:30 h becomes 2330). As both bongo and neuston data were included in the model, and these tows typically took place within $2 \mathrm{~h}$ of each other, the mean time between the two tows was used. We included the proportion of the moon illuminated as a means of quantifying moon phase, with 0 representing a new moon, and 1 a full moon. Data were downloaded from the United States Navy Astronomical Applications Department (http:// www.usno.navy.mil/USNO/).

Data from three National Oceanic and Atmospheric Administration (NOAA) buoys in the northern GOM were used to examine wind speed data. Daily means were calculated from hourly data, downloaded from buoys \#42001 (longitude -89.67 , latitude 
Table 1. Details of sampled SEAMAP stations between 1982 and 2006 across the northern GOM. Some data from 1987 and 1988 were not available due to loss of archives.

\begin{tabular}{|c|c|c|c|c|}
\hline Year & Cruise start & Cruise end & $\begin{array}{l}\text { No. of sampled } \\
\text { stations (stations } \\
\text { containing bluefin } \\
\text { tuna larvae) }\end{array}$ & $\begin{array}{l}\text { No. of stations } \\
\text { with environmental } \\
\text { data complete } \\
\text { (stations containing } \\
\text { bluefin tuna larvae) }\end{array}$ \\
\hline 1982 & 15 April & 25 May & $129(43)$ & $42(23)$ \\
\hline 1983 & 22 April & 23 May & $111(28)$ & $65(21)$ \\
\hline 1984 & 21 April & 16 May & $142(13)$ & $30(4)$ \\
\hline 1986 & 22 April & 21 May & $147(22)$ & $58(12)$ \\
\hline 1987 & 18 April & 20 May & $240(?)$ & $1(0)$ \\
\hline 1988 & 19 April & 26 May & $196(?)$ & $2(1)$ \\
\hline 1989 & 26 April & 19 May & $147(28)$ & $45(12)$ \\
\hline 1990 & 21 April & 29 Jun & $272(20)$ & 97 (11) \\
\hline 1991 & 17 April & 10 May & $149(16)$ & $30(2)$ \\
\hline 1992 & 22 April & 23 May & $166(21)$ & $20(7)$ \\
\hline 1993 & 26 April & 15 June & $201(16)$ & $20(3)$ \\
\hline 1994 & 28 April & 9 June & $169(17)$ & $34(5)$ \\
\hline 1995 & 19 April & 7 June & $265(34)$ & $88(20)$ \\
\hline 1996 & 17 April & 24 May & $189(14)$ & $65(8)$ \\
\hline 1997 & 17 April & 9 June & $205(17)$ & $76(15)$ \\
\hline 1998 & 26 April & 30 May & $171(18)$ & $51(8)$ \\
\hline 1999 & 24 April & 31 May & $182(16)$ & $68(11)$ \\
\hline 2000 & 20 April & 26 May & $170(18)$ & $66(11)$ \\
\hline 2001 & 18 April & 29 May & $183(30)$ & $56(17)$ \\
\hline 2002 & 19 April & 28 May & 157 (13) & $59(9)$ \\
\hline 2003 & 13 May & 30 May & $97(24)$ & $37(11)$ \\
\hline 2004 & 13 May & 30 May & $86(17)$ & $28(9)$ \\
\hline 2006 & 23 April & 16 July & $162(14)$ & $63(11)$ \\
\hline
\end{tabular}

25.90), \#42002 (-93.67, 25.79) and \#42003 (-85.59, 25.97) for each year. The daily mean wind speed for the closest buoy to each sampled station, for the sampled date, was included as the last environmental variable. On the rare occasion that data were unavailable for the closest buoy to a station, data from the next closest buoy were used instead.

When they were present, numbers of bluefin tuna larvae caught tended to be variable, and were often low ( $<5$ per tow). The model was therefore constructed to predict the presence or absence of bluefin tuna larvae only, without regard to the number of larvae collected. Data from each bongo net tow for which temperature, salinity and plankton volume data were available were collated, and the presence or absence of bluefin tuna larvae was noted (Table 1). A neuston net tow was completed at all bongo net stations considered in these analyses, and so if either or both nets at one station caught bluefin tuna larvae, the station was considered to be a 'positive' station. Both bongo and neuston net tows commonly collected the larvae of other Atlantic tunas, such as Auxis species, comprising either Auxis rochei (bullet tuna) or Auxis thazard (frigate tuna), Katsuwonus pelamis (skipjack tuna), Euthynnus alletteratus (little tunny) and other Thunnus species. These were likely a mix of Thunnus albacares (yellowfin tuna) and Thunnus atlanticus (blackfin tuna), with small abundances of bigeye tuna Thunnus obesus (bigeye tuna) and Thunnus alalunga (albacore), but these larvae were all distinct from bluefin tuna. The presence or absence of the three most abundant species of other tunas (Thunnus species, $K$. pelamis and Auxis species) were therefore also included as three categorical variables.

As a non-statistical, exploratory tool, relationships between bluefin tuna larvae occurrences and continuous environmental variables were initially defined using a simple preference model approach (Cock, 1978). Each variable was divided into 15 bins, with an approximately equal number of observations contained in each bin. The proportion of stations within each bin which contained bluefin tuna larvae was calculated, and plotted. Although this technique does not require normally distributed data, strongly skewed variables can make interpretation difficult. Plankton volume data and depth data were strongly rightskewed, and were therefore $\log (x+1)$ transformed before this analysis. 
Table 2. Pearson product moment correlations between all continuous environmental variables.

\begin{tabular}{|c|c|c|c|c|c|c|c|c|c|c|c|c|c|}
\hline T100 & 0.16 & & & & & & & & & & & & \\
\hline T200 & 0.14 & 0.91 & & & & & & & & & & & \\
\hline So & -0.01 & $-\overline{0.03}$ & -0.03 & & & & & & & & & & \\
\hline S100 & 0.02 & -0.04 & -0.08 & 0.12 & & & & & & & & & \\
\hline S200 & 0.08 & 0.73 & $\underline{0.78}$ & 0.03 & 0.23 & & & & & & & & \\
\hline Plankton log & -0.11 & -0.03 & $-\overline{0.05}$ & -0.03 & 0.04 & -0.01 & & & & & & & \\
\hline Depth log & 0.31 & 0.03 & 0.02 & 0.14 & 0.03 & -0.01 & -0.09 & & & & & & \\
\hline Date & 0.62 & 0.04 & 0.02 & -0.13 & -0.04 & -0.05 & -0.05 & -0.01 & & & & & \\
\hline Time & 0.05 & 0.03 & 0.02 & 0.001 & -0.03 & 0.02 & -0.07 & -0.01 & -0.04 & & & & \\
\hline Wind & -0.26 & -0.04 & -0.02 & 0.03 & -0.03 & 0.01 & -0.05 & -0.04 & -0.22 & 0.004 & & & \\
\hline Moon phase & 0.02 & 0.05 & 0.01 & -0.01 & -0.03 & -0.03 & -0.04 & 0.03 & -0.05 & 0.003 & 0.04 & & \\
\hline Longitude & 0.2 & 0.05 & 0.03 & 0.18 & 0.08 & 0.05 & 0.12 & 0.1 & -0.09 & 0.01 & -0.17 & 0.05 & \\
\hline \multirow{2}{*}{ Latitude } & -0.37 & -0.1 & -0.09 & -0.13 & -0.08 & -0.1 & 0.13 & -0.52 & 0.02 & -0.02 & 0.07 & -0.08 & -0.11 \\
\hline & TO & T100 & T200 & So & S100 & S200 & $\begin{array}{l}\text { Plankton } \\
\log \end{array}$ & $\begin{array}{c}\text { Depth } \\
\log \end{array}$ & Date & Time & Wind & $\begin{array}{c}\text { Moon } \\
\text { phase }\end{array}$ & Longitude \\
\hline
\end{tabular}

Temperature is abbreviated to ' $T$ ', and salinity to ' $\mathrm{S}$ ', at the surface (0), 100 and $200 \mathrm{~m}$ depth. Significant correlations at $P<0.05$ are shown in bold, and strong correlations of $r>0.75$ are underlined.

Pearson product moment cross-correlations were generally low among all pairs of variables. However, strong $(r>0.75)$ relationships existed between temperatures at $100 \mathrm{~m}$ versus temperatures at $200 \mathrm{~m}$, and between temperatures at $200 \mathrm{~m}$ versus salinities at $200 \mathrm{~m}$ (Table 2). As temperature at $200 \mathrm{~m}$ showed a slightly more cohesive trend with bluefin tuna larval occurrences than either temperature at $100 \mathrm{~m}$ or salinities at $200 \mathrm{~m}$, this variable was retained, and the remaining two variables were excluded from the classification tree analysis. This left 15 variables as input parameters for classification tree analysis: surface temperature, temperature at $200 \mathrm{~m}$ depth, surface salinity, salinity at $100 \mathrm{~m}$ depth, standardized plankton volumes, water depth, day of the year, time of day, wind speed, moon phase, latitude, longitude, and presence or absence of larvae of the other three species of tuna. As a comparison with larval bluefin tuna associations, the sea surface temperature associations of Auxis species, K. pelamis, E. alletteratus and other Thunnus species were also calculated and displayed.

The remaining variables were input into a classification tree model, using DTREG software (Brentwood, TN, USA; Sherrod, 2003). Classification tree modeling splits a data set into increasingly small and homogeneous subsets, with each split made using the variable which provides the greatest improvement in the homogeneity of the two resulting groups (De'ath and Fabricius, 2000; Castellon and Sieving, 2006). The aim of this procedure was to define habitat conditions which had the highest likelihood of occurrence of bluefin tuna larvae. The classification tree approach was suited to our data set as it is a non-parametric procedure which can cope with non-linear relationships and interaction amongst predictor variables (Franklin, 1998; De'ath and Fabricius, 2000; Vayssieres et al., 2000). Although construction of classification trees is a non-parametric technique, strongly skewed data and outliers can still affect model performance. The distributions of all continuous variables were examined, and a fourth-root transformation was applied to temperature at $200 \mathrm{~m}$, and salinity at the surface, and at $100 \mathrm{~m}$. The $\log$ transforms already applied to plankton volume and water depth were retained.

The Gini goodness-of-fit measure was used to determine optimum splits. To avoid model over-fitting, a minimum node size of ten observations was required to complete a split. Each continuous variable was divided by the program into 2000 categories, to make the splits of each variable as accurate as possible. $\mathrm{V}$-fold cross-validation, with ten partitions, was used to validate the classification tree model (De'ath and Fabricius, 2000). The DTREG program also has the ability to set a misclassification 'cost' for the model, in order to preferentially avoid false positive or false negative, results. We used iterative analysis to find the optimum value for the misclassification cost, in terms of the number of positive, and negative, stations classified correctly by the model. To construct a model with the highest degree of generality possible, $10 \%$ of the original data set was withheld from the initial analysis as a 'test' data set. All stations from cruise leg 2 of 1995 were included in the 'test' data set, to allow us to plot the success of the model on unseen data across the GOM for one entire cruise leg. The rest of the 'test' data set was selected randomly. The 
remaining $90 \%$ of the data were used as a 'training' data set. The ability of the model constructed using the training data set to correctly predict favorable bluefin tuna habitat for the test data set was then assessed, as a way of providing out of model validation. The accuracy of the model was assessed by comparing the modeled probability of larval bluefin tuna occurrence at each station to the actual observed larval data. Our aim was to define a model which would correctly classify at least $80 \%$ of positive larval bluefin tuna stations.

Throughout the larval surveys, bluefin tuna larvae were most commonly found in low numbers, signifying a sparse and patchy distribution (Richards et al., 1989), and a high likelihood that sampling would miss larvae present in favorable habitat. This suggested that even after formulation of a multivariate model, a considerable proportion of favorable habitat was likely to be unoccupied by larval bluefin tuna. Our objective was to construct the classification tree model in such a way as to inclusively define the range of potentially favorable larval bluefin tuna habitat, rather than to assume that all negative stations had been located in unfavorable habitat. This was achieved by adjusting the misclassification cost of the classification tree model.

As a visual aid, the generated probabilities for four example years (1983, 1995, 1997 and 2003) were contoured, using kriging in SURFER 9, and the bluefin tuna larvae catch locations for each of these years were overlaid. These years were chosen because they represented a range through time, with contrasting oceanographic conditions, and sufficient bluefin tuna larval occurrences to test model accuracy. As two cruise legs were usually completed each year, with the same stations repeated between legs, results from one leg of each cruise only were shown in these plots. Cruise leg 2 of 1995 was chosen, as all larval bluefin tuna distributions from this leg were generated from out-of-model validation, and could be compared to predictions generated from other years.

\section{RESULTS}

\section{Preference indices and variable selection}

Between 1982 and 2006, 1101 stations with all environmental and bluefin tuna larval data were available (Table 1). Bluefin tuna larvae were found at $21 \%$ of these stations in at least one net type, and were distributed across the GOM (Fig. 1). Larvae were collected in both nets at $5.3 \%$ of stations, in the neuston net only at $6.1 \%$ of stations, and in bongo nets only at $8.6 \%$ of stations. Larvae were typically very small, with mean lengths of $3.7 \mathrm{~mm}$ in bongo net samples and $5.3 \mathrm{~mm}$ in neuston net samples.

Data from all years were used to examine associations between bluefin tuna larvae and different environmental conditions (Fig. 2a,b). Larvae were most likely to be collected at moderate sea surface temperatures, between 25 and $28^{\circ} \mathrm{C}$ (Fig. 2a). In contrast, bluefin tuna larvae were associated with lower temperatures at both 100 and $200 \mathrm{~m}$ depth. Larvae were proportionally more abundant where salinities at $100 \mathrm{~m}$ depth were higher than around 36.3. However, no trend was apparent for salinities at the surface, and at $200 \mathrm{~m}$ depth (Fig. 2a). Bluefin tuna larvae were also more likely to be found at lower longitudes (stations farther west). Stations with higher plankton volumes were most likely to be positive for bluefin tuna larvae, as were stations of intermediate depth (Fig. 2b). In terms of temporal variables, larvae were proportionally more abundant from the middle to the end of May, and at darker (closer to the new moon) moon phases (Fig. 2b). There were no visible trends with time of day, and wind speed. Stations containing the larvae of other Thunnus species or of $\mathrm{K}$. pelamis were slightly more likely to contain bluefin tuna larvae, whereas the reverse was true for stations containing Auxis species larvae (Fig. 2b).

The proportion of positive stations within each bin of each variable was generally no higher than $30-40 \%$, indicating that even within the most favorable conditions for each variable, $60-70 \%$ of stations would still be unoccupied by bluefin tuna larvae. A scatterplot of temperature and salinity at the surface (as an example) showed that although bluefin tuna larvae were more common at stations with high salinities and intermediate temperatures, conditions at positive and negative stations overlapped considerably (Fig. 3).

\section{Classification tree model}

As the primary interest was in defining potentially favorable habitat for larval bluefin tuna, rather than excluding all negative stations, it was preferable that the model be constructed more to avoid false positives (bluefin tuna larvae at theoretically unfavorable stations) than false negatives (no larval bluefin tuna at theoretically favorable stations). To achieve this, the misclassification cost in DTREG was set to make false positives five times more costly than false negatives. At values lower than three, a large proportion of positive bluefin tuna stations were classified as being in unfavorable habitat. At values larger than five, the misclassification of negative stations became unacceptably high, with little improvement in correct 
(a)
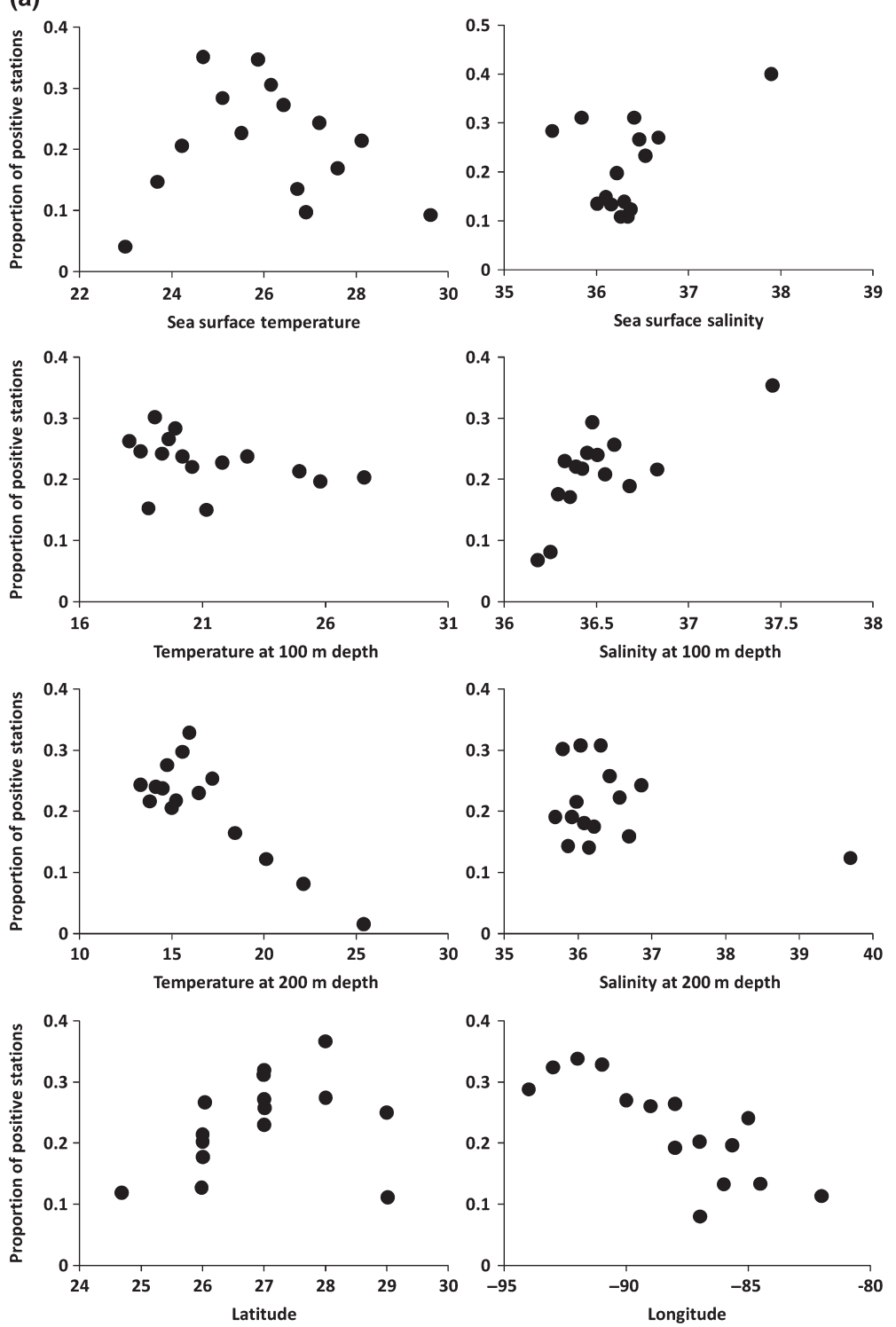

Figure 2. ( $a, b)$ Proportions of positive stations for bluefin tuna larvae for differing levels of 14 environmental variables, for all data sampled between 1982 and 2006. Both plankton volume and depth data were log-transformed. classification of positive stations (Fig. 4). The accuracy of the model with varying misclassification costs was assessed for both the training data set used to construct the model and for the test data set used for out of model validation. The size of the classification tree for each model was also recorded (measured by the number of terminal nodes), as the structure of the tree changed to accommodate each misclassification cost. Larger trees (such as those generated when the misclassification cost was set at 3 or 4 ) tended to be comparatively more accurate for the training data set, but less so for the test data set, suggesting a tendency towards over-fitting, and a loss of generality. The chosen model, with a misclassification cost of 5 , was $89.9 \%$ accurate for positive stations and 57.0\% accurate for negative stations using the training data set, and $82.6 \%$ accurate for positive stations and $57.5 \%$ accurate for negative stations using the test data set. This minor loss of power between the training and the test data set suggested that the model was sufficiently general, and was not overfit to the training data set.

The classification tree model chosen initially split the data by temperature at $200 \mathrm{~m}$ depth (Fig. 5), with temperatures above $21.0^{\circ} \mathrm{C}$ highly unfavorable. Samples taken after 8 May were more also likely to contain larval bluefin tuna. Earlier, larvae were still collected where sea surface salinities and sea surface temperatures were higher. For stations sampled after 8 May, larvae were more likely to be found at darker moon phases (where the fraction of the moon illuminated 
(b)
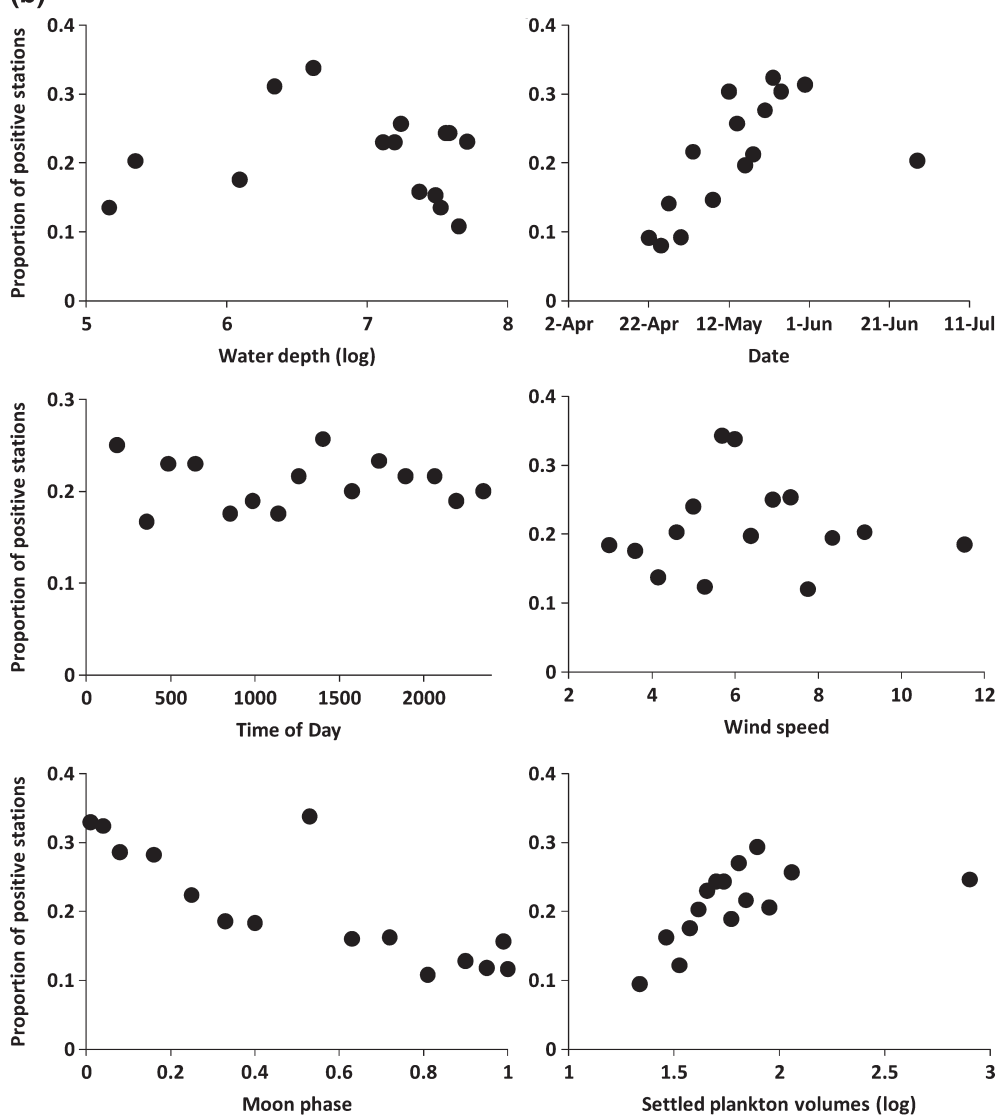

Figure 2. (Continued).

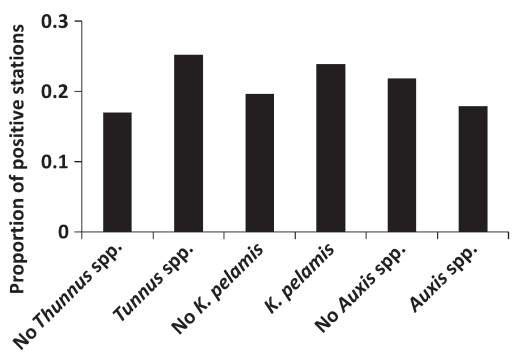

was $<0.5)$, and where sea surface temperatures were $<28.5^{\circ} \mathrm{C}$. At brighter moon phases, some larvae were still collected west of $87^{\circ} \mathrm{W}$, where plankton volumes were higher (Fig. 5).

To visualize the results of the model within specific years, the generated probabilities for 4 yr (Leg 2 surveys from 1983, 1995 and 1997, and Leg 1 from 2003) were contoured, and plotted, with locations of bluefin tuna catches overlaid (Fig. 6). Generally, habitat within the LC in the eastern GOM was less favorable, as were warm-core rings, and cooler water on the continental shelf. The location and size of favorable habitat was highly variable between years, which was reflected in the locations of larval bluefin tuna catches.
However, as expected, many theoretically favorable stations were negative for larval bluefin tuna.

To examine how these 'rates of occupancy' had changed over time, the proportion of stations which supported larval bluefin tuna were plotted for all years, except 1987 and 1988, between 1982 and 2006. Data from all sampled stations, and for all stations in theoretically favorable habitat, are shown in Fig. 7. Considering only stations in favorable habitat, there were higher occupancy rates in 1982 and 1983, with lower values thereafter. Given no habitat information, the chances of collecting a bluefin tuna larva at any sampled station over the survey period was $21.0 \%$. However, if only stations classified as being in favorable 
Figure 3. Scatterplot of sea surface temperatures, and sea surface salinities of all sampled stations, 1982-2006. Stations where bluefin tuna larvae were caught (positive stations) are shown as filled diamonds, while stations where no bluefin tuna larvae were caught (negative stations) are shown as $\mathrm{x}$.

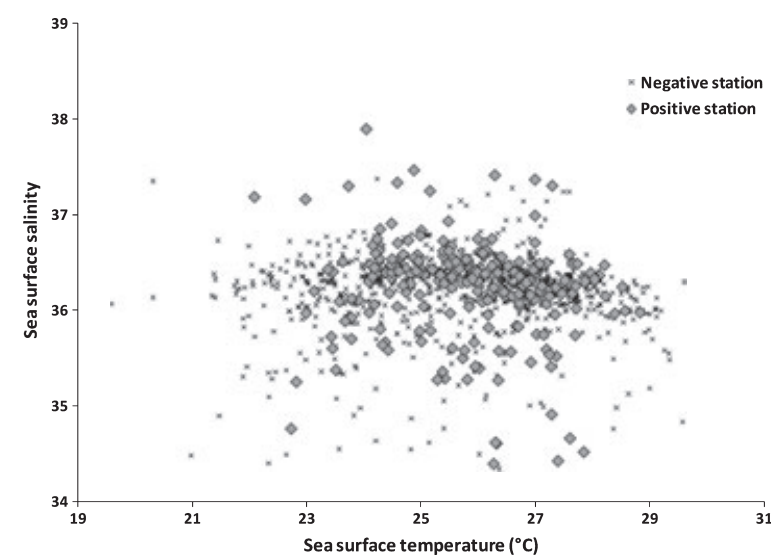

habitat were included, this probability improved to $35.5 \%$. This improvement in probability varied among years, with some years showing up to a $200 \%$ improvement (from 14 to $44 \%$ in 1994) in the probability of catching a bluefin tuna larva if only favorable habitat was considered, and other years showing a marginal improvement (Fig. 7). The mean improvement among years was 65\%. Overall, 364 (33\%), of stations sampled between 1982 and 2006, and examined here, had $<3.5 \%$ probability of collecting bluefin tuna larvae, based on environmental conditions.

Other tuna species and sea surface temperature

The larvae of other Atlantic tunas were frequently found in much warmer water than were larval bluefin tuna (Fig. 8). Auxis species larvae were collected across most water temperatures, and E. alletteratus showed a slight association with warmer waters. However, the larvae of K. pelamis and other Thunnus species (not including bluefin tuna) showed a strong association with very warm waters.

\section{DISCUSSION}

Classification tree analysis showed that whereas bluefin tuna larvae in the northern GOM were collected in a variety of oceanographic conditions, they were very rare or absent in certain habitats. Given their small size, and thus young age of around 7 days or less (Brothers et al., 1983), the larval bluefin tuna collected were likely to be located in the same water mass in which they were spawned. If larvae were largely
Figure 4. Effect of varying misclassification costs on the performance of the classification tree model. Classification successes for positive and negative stations for bluefin tuna larvae are shown for the training data set (top), and test data set (bottom). The size of the generated classification tree (measured by the number of terminal nodes) is also shown for the training data set.
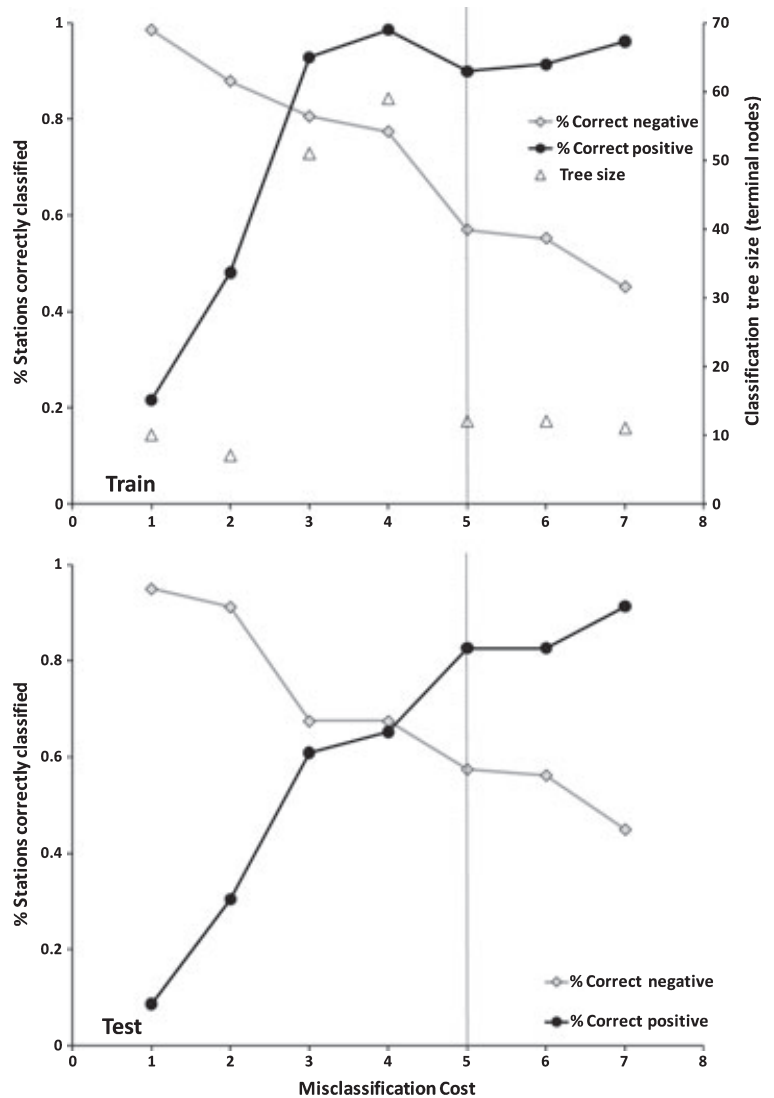

absent from a habitat type, it suggests that the adults were not spawning there.

Bluefin tuna larvae were less likely to be collected where water temperatures at $200 \mathrm{~m}$ depth were high. Stations with higher temperatures at depth were most likely to have been in the LC, or within warm LC rings, where warmer waters penetrate to deeper depths (Schroeder et al., 1974). Although high water temperatures might be most favorable for egg hatching (Miyashita et al., 2000) and fast larval growth rates (Brothers et al., 1983; Houde, 1989), retention conditions within the LC would be poor. Any larvae spawned within the LC would be advected out of the GOM and northwards along the south-eastern US coast within a period of days (McGowan and Richards, 1989). In addition, physiological processes of adult bluefin tuna may be compromised when they encounter very warm waters (Blank et al., 2004), such 
Figure 5. Classification tree model for predicting the presence or absence of bluefin tuna larvae in the northern GOM. The number of samples at each node is shown, as is the misclassification rate (percent). The importance of all included variables in the generation of the tree is also given.

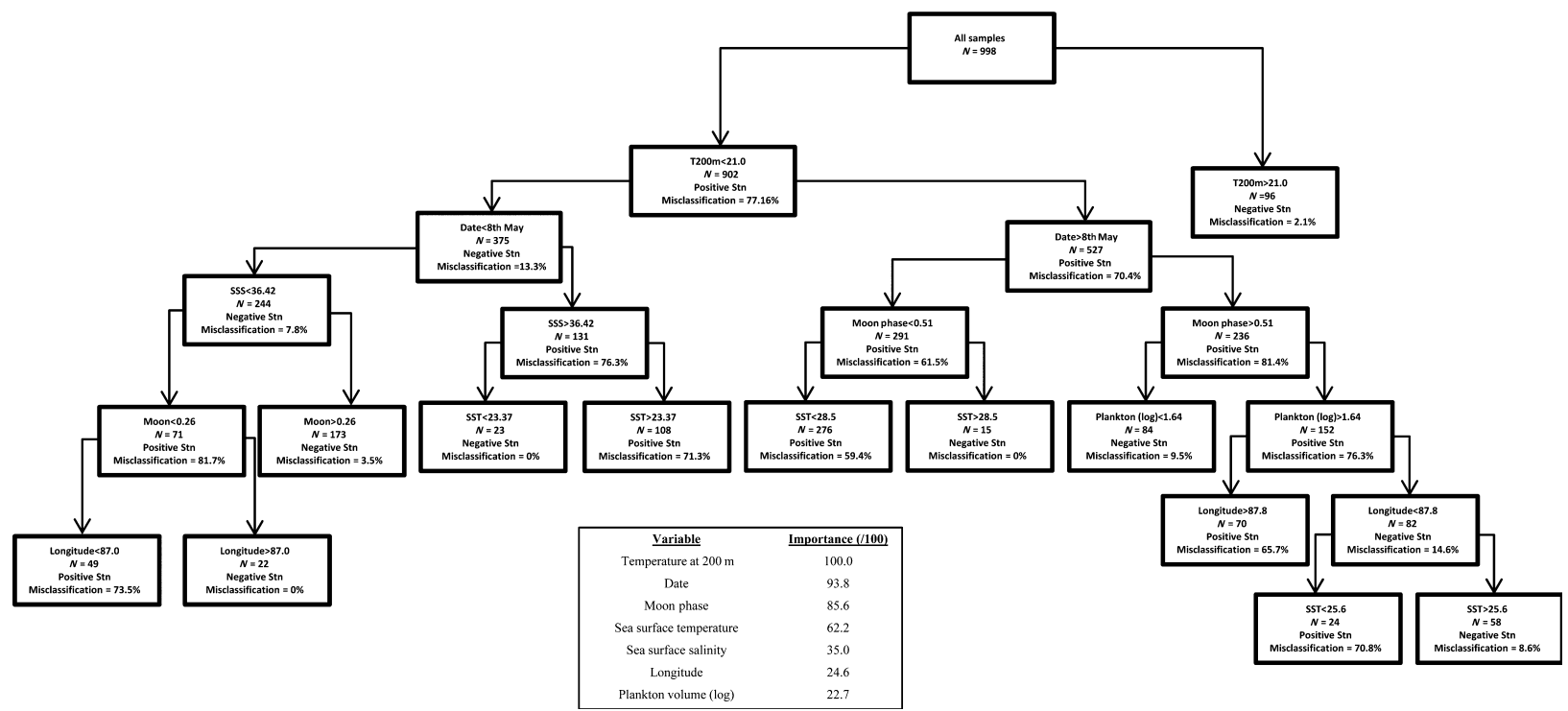

Figure 6. Predicted probabilities from classification tree analysis of collecting at least one bluefin tuna larvae across all sampled stations in cruise leg 2 of 1983, 1990 and 1997, and cruise leg 1 of 2003. All sampled stations, and larval bluefin tuna catch locations, are shown. Probabilities were kriged between stations to aid interpretation, but this should not be taken as a means to predict habitat between stations.

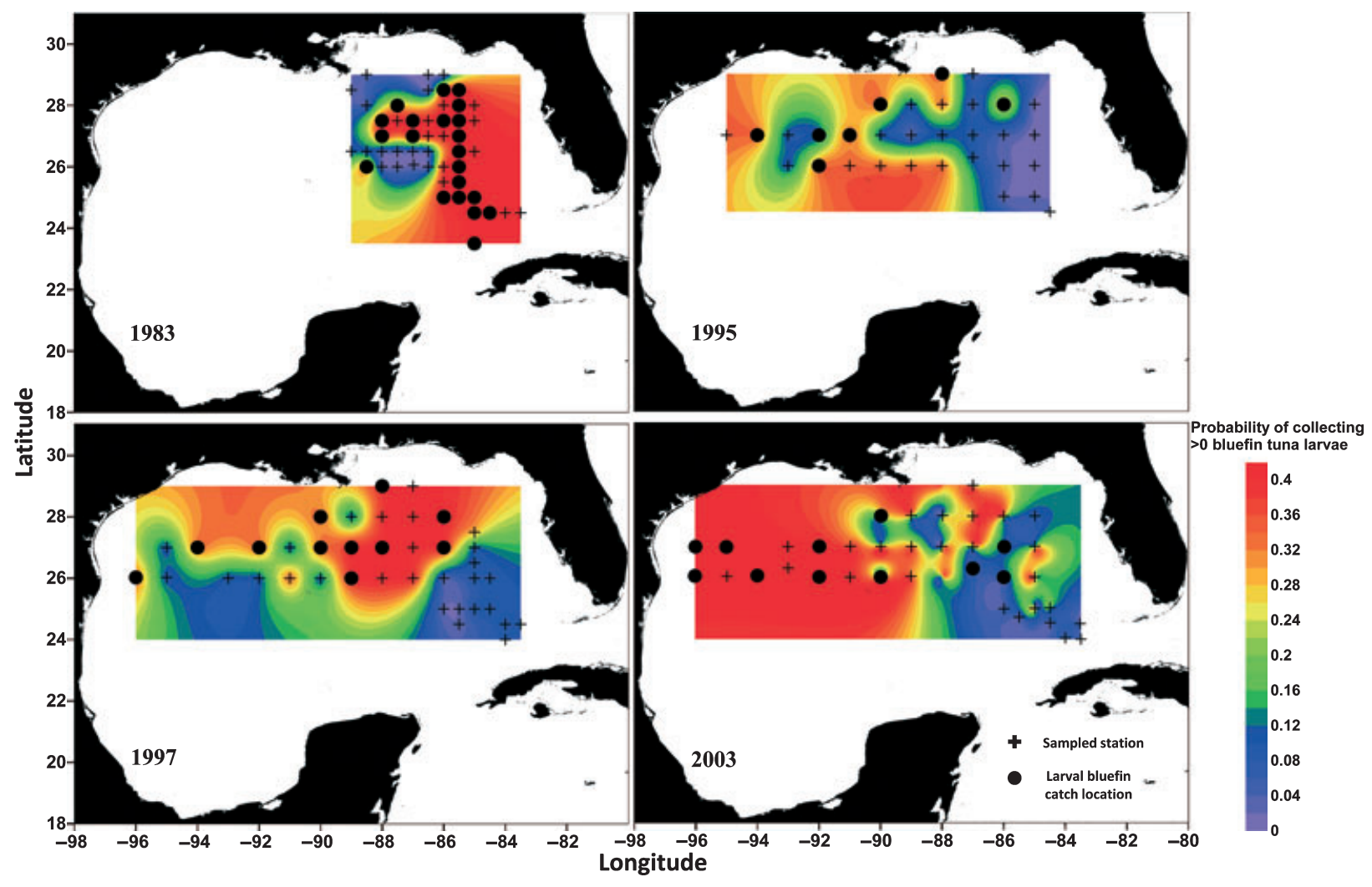

(C) 2010 Blackwell Publishing Ltd, Fish. Oceanogr., 19:6, 526-539. 
Figure 7. Proportion of stations occupied by bluefin tuna larvae in each sampled year for all habitat, and predicted favorable habitat (top). The percentage improvement in the chance of collecting bluefin tuna larvae within predicted favorable habitat, as opposed to all habitat, is also shown (bottom).
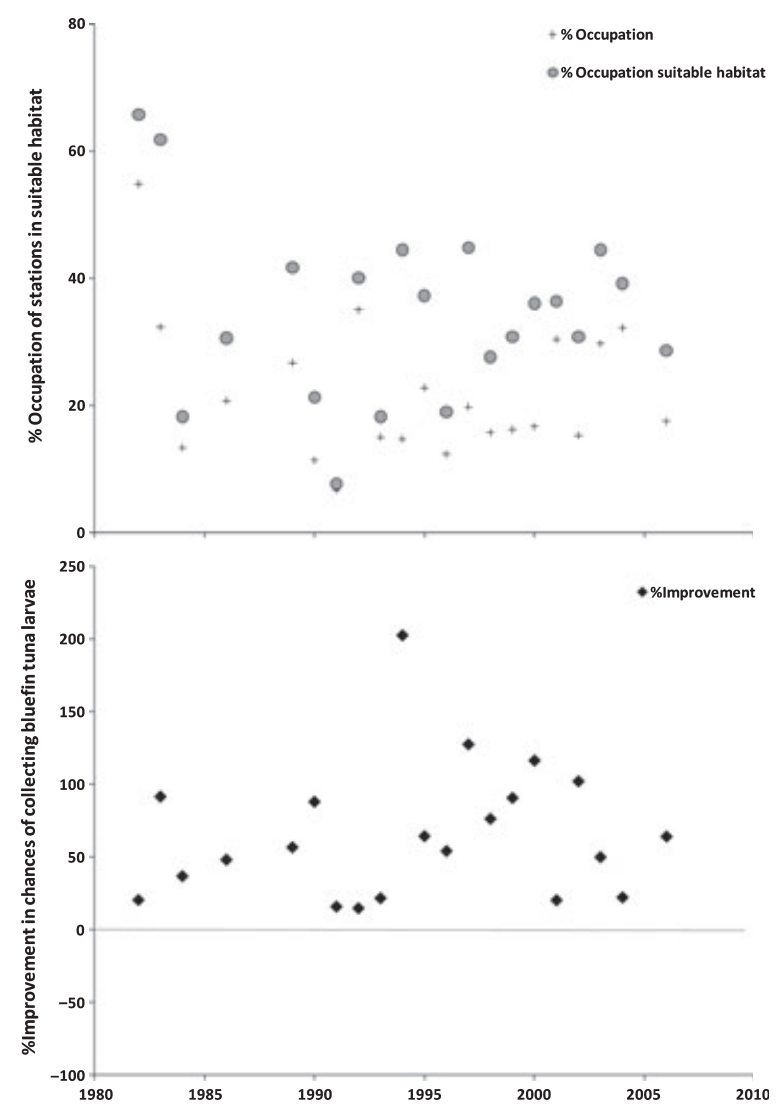

Figure 8. Proportions of positive stations for larvae of other tunas for differing levels of sea surface temperature, for all sampled years from 1982 to 2006.

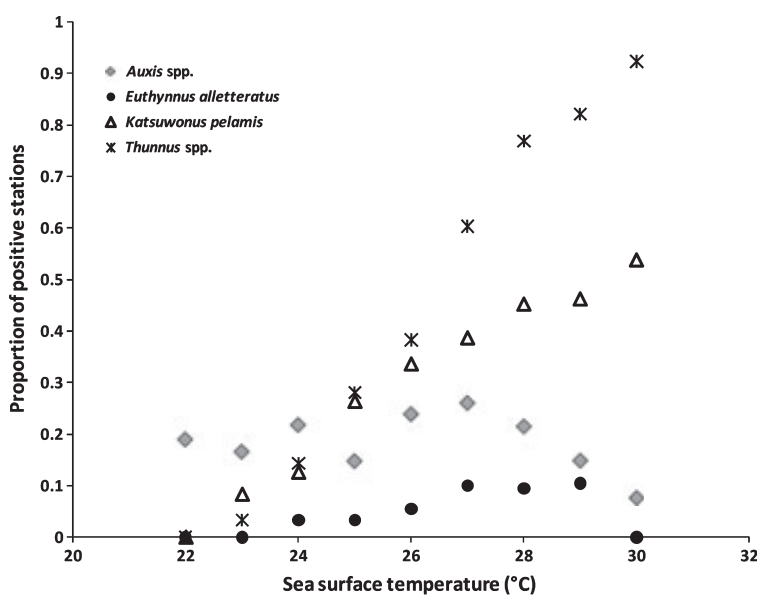

as those found within LC water in late spring (MullerKarger et al., 1991; Zavala-Hidalgo et al., 2002). Tagging data have shown that adult bluefin tuna do not tend to linger within the LC when migrating into the GOM (Block et al., 2001), and may show deep diving behavior when crossing it, potentially to avoid very warm waters (Teo et al., 2007b). A combination of poor larval retention and stressful conditions for adult bluefin tuna therefore makes LC waters a largely unsuitable spawning location.

Bluefin tuna are thought to prefer sea surface temperatures above $24^{\circ} \mathrm{C}$ for spawning (Mather et al., 1995; Schaefer, 2001; Garcia et al., 2005), and have been previously shown to prefer areas in the GOM with surface temperatures of between 24 and $27^{\circ} \mathrm{C}$ (Teo et al., 2007a). Adult bluefin tuna are present in the GOM as early as winter; however, they are not usually in spawning condition until mid April onwards (Block et al., 2001). This suggests that some environmental variable exists that may trigger spawning, such as temperature (Fitzhugh and Hettler, 1995) or photoperiod (Carrillo et al., 1989), a conclusion supported by the proportional increase in catches in bluefin tuna larvae in this study at stations sampled after 8 May. However, favorable temperatures for larvae collected in the Mediterranean Sea were lower than in the GOM $\left(24-25^{\circ} \mathrm{C}\right.$, Garcia et al., 2005; 21; $5-26.5^{\circ} \mathrm{C}$, Alemany et al., 2010). This may suggest that although spawning is initiated by environmental thresholds, some of the upper temperature associations shown here are likely to be proxies for the avoidance of specific water masses that would result in poor larval retention, slower development or higher mortality.

Earlier in the spawning season, bluefin tuna larvae were noticeably absent from waters with low surface temperatures and salinities, which were usually on the continental shelf, or of continental shelf origin. These waters are generally higher in chlorophyll concentrations than open GOM waters (Muller-Karger et al., 1991), and may be higher in nutrients and sediments, especially around the Mississippi River delta (Turner and Rabalais, 1991). Dense blooms of phytoplankton frequently occur on the continental shelf as a result of this nutrient-rich, lower salinity inflow (Lohrenz et al., 1990). While these continental shelf waters may provide high concentrations of potential larval fish food items, such as zooplankton (Young and Davis, 1990), they may also contain high concentrations of planktonic predators (Bakun, 2006). Preflexion larval tuna diets are usually specialized, and many target appendicularians, before switching to piscivory at larger sizes (Llopiz et al., 2010). Pelagic tunicates such as appendicularians are well adapted to oligotrophic open 
oceans (Sommer and Stibor, 2002), and the reliance of larval tunas on these organisms suggests adaptation to nutrient-poor waters. Favorable habitat for bluefin tuna larvae in the GOM was therefore defined as moderately warm waters outside of the LC, and LC eddies, and outside of cooler, higher chlorophyll continental shelf waters.

Bluefin tuna larvae were more likely to be found around the new moon (between the last and first quarters) than around the full moon. Although adult bluefin tuna in the North Atlantic (Wilson et al., 2005) and Pacific (Block and Farwell, 2005) adjust their feeding behavior during the full moon, there is no evidence that spawning activity is also modulated by moon phase. Instead, it is likely that the ability of larval bluefin tuna to detect, and avoid, sampling nets at night would be enhanced during a full moon, when the sky is lighter, thus contributing to lower catches of larvae (Davis et al., 1990). However, further study is required to confirm this.

The precise reasons why adult bluefin tuna migrate large distances to spawn in the GOM remain unclear. Like many other large pelagic fishes, their spawning grounds are warm (Schaefer, 2001) and largely oligotrophic (Richardson, 2007). It has been suggested that natal homing may be important and that fish return to ancestral spawning grounds (Cury et al., 1998). This would imply that adult fish are spawning in comparatively favorable habitats within defined spawning locations. Although similarly warm, oligotrophic regions may be found in the Atlantic and Caribbean Seas, no evidence of large-scale spawning in these areas has been found. However, it remains possible that other spawning areas exist (Lutcavage et al., 1999). A few scattered larvae have previously been collected east of the Yucatan Peninsula, and off the east coast of the U.S.; some of these larvae appear likely to have originated from outside the Gulf of Mexico (McGowan and Richards, 1989; Rooker et al., 2007).

The model created in this study was useful for defining broad water masses in which bluefin tuna larvae were more likely to be collected. We find that $33 \%$ of stations examined here had a $<3.5 \%$ probability of positive catches. However, many stations within favorable habitat did not contain bluefin tuna larvae. Part of this result is likely to be related to catchability: larval bluefin tuna occurrences were patchy, and larvae were frequently caught in low numbers $(<5)$. Part of this may be due to gear inefficiencies and net avoidance, so the chances of missing larvae, even if they were present, may have been considerable. However, larvae of other Thunnus species were collected much more commonly than bluefin tuna larvae, and in alternative habitats, such as warmer LC water. This suggests that bluefin tuna larvae were indeed rare, possibly as a result of the depleted stock size (McAllister and Carruthers, 2008). Similar disparities between abundances of bluefin tuna and other tuna larvae have also been found in the Mediterranean (Garcia et al., 2005; Oray and Karakulak, 2005).

One limitation of the current model, in terms of the data used, was the coarse resolution of the sampling stations. This factor limits our ability to correlate larval abundance to finer-scale features, such as fronts, and frontal eddies. Adult bluefin tuna are capable of detecting and responding to oceanographic gradients (Medina et al., 2002; Royer et al., 2004; Wilson et al., 2005), and Richards et al. (1989) found bluefin tuna larvae concentrated along the LC front. Given the significance of finer-scale features to larval retention, feeding conditions and survival (e.g., Hinrichsen et al., 2003; Richardson, 2007), this is a considerable shortcoming. However, since 2008, finer-scale sampling targeting oceanographic features has been completed as part of the annual spring GOM larval surveys, with an emphasis on the use of satellite imagery to place stations and to provide environmental data. When processed, these data will allow us to better define favorable habitat for larval bluefin tuna, and refine the current model. In addition, current research is using satellite measurements of sea surface temperature, sea surface height and chlorophyll to act as proxies for many of the environmental parameters included in this model, and to investigate the influence of ocean fronts on larval distributions.

In conclusion, we find that larval bluefin tuna were rarely collected within Loop Current waters, warmcore rings, or cooler continental shelf waters within the GOM. The extent of favorable habitat was highly variable among years, which was reflected in the spatial variability of larval bluefin tuna catches, and onethird of all stations had a $<3.5 \%$ chance of collecting larvae. Given current issues with variability of data inputs, these models have high potential to significantly improve data inputs for the management of an iconic species.

\section{ACKNOWLEDGEMENTS}

The authors would like to thank W. J. Richards and A. Bakun for help on the original proposal for this work, suggestions and helpful comments, and sample identification. We also wish to thank staff at the NOAA-National Marine Fisheries Service Pascagoula laboratory for valuable assistance with data collection 
and provision, including W. Ingram, J. LyczkowskiSchultz, K. Williams, D. Drass, D. Hanisko and G. Zapfe. We thank all staff at the Polish Plankton Sorting and Identification Center in Szczecin, Poland, including M. Konieczna and L. Ejsymont. We also extend our gratitude to all the captains and crew of all the NOAA ships who collected data on the SEAMAP cruises. This work was funded by the Fisheries and the Environment (FATE) program within the National Marine Fisheries Service, and the National Research Council.

\section{REFERENCES}

Alemany, F., Garcia, A., Gonzalez-Pola, C. et al. (2010) Atlantic bluefin tuna and related species spawning habitat characterization: influence of environmental factors on larval abundance and distribution off Balearic archipelago (Western Mediterranean). Prog. Oceanogr. 86:21-38.

Bailey, K.M., Stabeno, P.J. and Powers, D.A. (1997) The role of larval retention and transport features in mortality and potential gene flow of Walleye Pollock. J. Fish Biol. 51:135154.

Bakun, A. (2006) Wasp-waist populations and marine ecosystem dynamics: navigating the 'predator pit'. Prog. Oceanogr. 68:271-288.

Blank, J.M., Morrissette, J.M., Landeira-Ferandez, A.M., Blackwell, S.B., Williams, T.D. and Block, B.A. (2004) In situ cardiac performance of Pacific bluefin tuna hearts in response to acute temperature change. J. Exp. Biol. 207:881-890.

Block, B.A. and Farwell, C.J. (2005) Migratory Movements of Pacific Bluefin Tuna Off California. San Diego: University of California, Sea Grant College Program, Research Completion Reports, Paper Fisheries 05/04, pp. 10.

Block, B.A., Dewar, H., Blackwell, S.B. et al. (2001) Migratory movements, depth preferences and thermal biology of Atlantic bluefin tuna. Science 293:1310-1314.

Block, B.A., Teo, S.L.H., Walli, A. et al. (2005) Electronic tagging and population structure of Atlantic bluefin tuna. Nature 434:1121-1127.

Brothers, E.B., Prince, E.D. and Lee, D.W. (1983) Age and growth of young-of-the-year bluefin tuna, Thunnus thynnus, from otolith microstructure. In: Proceedings of the International Workshop on Age Determination of Oceanic Pelagic Fishes: Tunas, Billfishes and Sharks. E.D. Prince \& L.M. Pulos (eds) Miami, FL, USA: NOAA Technical Report NMFS, No. 8: pp. 49-59.

Carey, F.G. and Lawson, K.D. (1973) Temperature regulation in free swimming bluefin tuna. Comp. Biochem. Physiol. A. Comp. Physiol. 44:375-392.

Carey, F.G. and Teal, J.M. (1966) Heat conservation in tuna fish muscle. Proc. Natl. Acad. Sci. USA 56:1464-1469.

Carrillo, M., Bromage, N., Zanuy, S., Serrano, R. and Prat, F. (1989) The effects of modifications in photoperiod on spawning time, ovarian development and egg quality in the sea bass (Dicentrarchus labrax L.). Aquaculture 81:351-365.

Castellon, T.D. and Sieving, K.E. (2006) Landscape history, fragmentation, and patch occupancy: models for a forest bird with a limited dispersal. Ecol. Appl. 16:2223-2234.
Cock, M.J.W. (1978) The assessment of preference. J. Anim. Ecol. 47:805-816.

Cury, P., Anneville, O., Bard, F.X., Fonteneau, A. and Roy, C. (1998) Obstinate North Atlantic bluefin tuna (Thunnus thynnus thynnus): an evolutionary perspective to consider spawning migration. Col. Vol. Sci. Pap. ICCAT 50:239-247.

Davis, T.L.O., Jenkins, G.P. and Young, J.W. (1990) Patterns of horizontal distribution of the larvae of southern bluefin tuna (Thunnus maccoyii) and other tuna in the Indian Ocean. J. Plankton Res. 12:1295-1314.

De'ath, G. and Fabricius, K.E. (2000) Classification and regression trees: a powerful yet simple technique for ecological data analysis. Ecology 81:3178-3192.

Dickhut, R.M., Deshpande, A.D., Cincinelli, A. et al. (2009) Atlantic bluefin tuna (Thunnus thynnus) population dynamics delineated by organochlorine tracers. Environ. Sci. Technol. 43:8522-8527.

Fitzhugh, G.R. and Hettler, W.F. (1995) Temperature influence on postovulatory follicle degeneration in Atlantic menhaden, Brevoortia tyrannus. Fish. Bull. 93:568-572.

Franklin, J. (1998) Predicting the distribution of shrub species in southern California from climate and terrain-derived variables. J. Veg. Sci. 9:733-748.

Garcia, A., Alemany, F., Velez-Belchi, P. et al. (2005) Characterization of the bluefin tuna spawning habitat off the Balearic Archipelago in relation to key hydrographic features and associated environmental conditions. Col. Vol. Sci. Pap. ICCAT 58:535-549.

Gilbes, F., Tomas, C., Walsh, J.J. and Muller-Karger, F.E. (1996) An episodic chlorophyll plume on the West Florida Shelf. Cont. Shelf Res. 16:1201-1207.

Hernandez, F.J. and Shaw, R.F. (2003) Comparison of plankton net and light trap methodologies for sampling larval and juvenile fishes at offshore petroleum platforms and a coastal jetty off Louisiana. Am. Fish. Soc. Symp. 36:15-38.

Hinrichsen, H.-H., Lehmann, A., Mollman, C. and Schmidt, J.O. (2003) Dependency of larval fish survival on retention/dispersion in food limited environments: the Baltic Sea as a case study. Fish. Oceanogr. 12:425-433.

Hinrichsen, H.-H., Kraus, G., Voss, R., Sepputtis, D. and Baumann, H. (2005) The general distribution pattern and mixing probability of Baltic sprat juvenile populations. J. Mar. Syst. 58:52-66.

Houde, E.D. (1989) Comparative growth, mortality and energetics of marine fish larvae: temperature and implied latitudinal effects. Fish. Bull. 87:471-495.

Ingram, G.W. Jr, Richards, W.J., Lamkin, J.T. et al. (2010) Annual indices of Atlantic bluefin tuna (Thunnus thynnus) larvae in the Gulf of Mexico developed using delta-lognormal and multivariate models. Aquat. Living Resour. 23:35-47.

Lasker, R. (1975) Field criteria for survival of anchovy larvae: the relation between inshore chlorophyll maximum layers and successful first feeding. Fish. Bull. 73:453-462.

Llopiz, J.K., Richardson, D.E., Shiroza, A., Smith, S.L. and Cowen, R.K. (2010) Distinctions in the diets and distributions of larval tunas and the important role of appendicularians. Limnol. Oceanogr. 55:983-996.

Lohrenz, S.E., Dagg, M.J. and Whitledge, T.E. (1990) Enhanced primary production at the plume/oceanic interface of the Mississippi River. Cont. Shelf Res. 10:639-664.

Lutcavage, M.E., Brill, R.W., Skomal, G.B., Chase, B.C. and Howey, P.W. (1999) Results of pop-up satellite tagging of spawning size class fish in the Gulf of Maine: do North 
Atlantic bluefin tuna spawn in the mid-Atlantic? Can. J. Fish. Aquat. Sci. 56:173-177.

Mather, F.J. III, Mason, J.M. Jr and Jones, C.A. (1995) Historical Document: Life History and Fisheries of Atlantic Bluefin Tuna. NOAA Technical Memorandum NMFS-SEFSC-370. Miami, Florida, USA: National Oceanic and Atmospheric Administration, pp. 165.

McAllister, M.K. and Carruthers, T. (2008) 2007 stock assessment and projections for western Atlantic bluefin tuna using a BSP and other SRA methodology. Col. Vol. Sci. Pap. ICCAT 64:1206-1270 SCRS/2007/143.

McGowan, M.F. and Richards, W.J. (1989) Bluefin Tuna, Thunnus thynnus, larvae in the Gulf Stream off the southeastern United States: satellite and shipboard observations of their environment. Fish. Bull. 87:615-631.

Medina, A., Abascal, F.J., Megina, C. and Garcia, A. (2002) Stereological assessment of the reproductive status of female Atlantic northern bluefin tuna during migration to Mediterranean spawning grounds through the strait of Gibraltar. J. Fish Biol. 60:203-217.

Miyashita, S., Yuji, T., Yoshifumi, S. et al. (2000) Embryonic development and effects of water temperature on hatching of the bluefin tuna, Thunnus thynnus. Suisan Zoshoku 48:199_ 207.

Muller-Karger, F.E., Walsh, J.J., Evans, R.H. and Meyers, M.B. (1991) On the seasonal phytoplankton concentration and sea surface temperature cycles of the Gulf of Mexico as determined by satellites. J. Geophys. Res. 96:12645-12665.

Oey, L.-Y., Ezer, T. and Lee, H.-C. (2005) Loop Current, rings and related circulation in the Gulf of Mexico: a review of numerical models and future challenges. In: Circulation in the Gulf of Mexico: Observations and Recent Models. W. Sturges \& A. Lugo-Fernandez (eds), Geophysical Monograph Series 161, Washington, DC: American Geophysical Union, pp. 31-56.

Oray, I.K. and Karakulak, F.S. (2005) Further evidence of spawning of bluefin tuna (Thunnus thynnus L., 1758) and the tuna species (Auxis rochei Ris., 1810, Euthynnus alletteratus Raf., 1810) in the eastern Mediterranean Sea: preliminary results of TUNALEV larval survey in 2004. J. Appl. Ichthyol. 21:236-240.

Restrepo, V.R. (1996) Report of the TAB workshop: a research planning workshop for Atlantic bluefin tuna tagging studies. Col. Vol. Sci. Pap. ICCAT 45:228-244.

Richards, W.J. (1976) Spawning of bluefin tuna (Thunnus thynnus) in the Atlantic Ocean and adjacent seas. Col. Vol. Sci. Pap. ICCAT 5:267-278.

Richards, W.J., Leming, T., McGowan, M.F., Lamkin, J.T. and Kelley-Fraga, S. (1989) Distribution of fish larvae in relation to hydrographic features of the loop current boundary in the Gulf of Mexico. Rapp. Reun. Cons. Int. Explor. Mer. 191:169-176.

Richards, W.J., McGowan, M.F., Leming, T., Lamkin, J.T. and Kelley, S. (1993) Larval fish assemblages at the loop current boundary in the Gulf of Mexico. Bull. Mar. Sci. 53:475-537.

Richardson, D.E. (2007) Physical and Biological Characteristics of Billfish Spawning Habitat in the Straits of Florida. PhD dissertation, Miami, FL, USA: University of Miami, pp. 206.

Rooker, J.R., Bremer, J.R.A., Block, B.A. et al. (2007) Life history and stock structure of Atlantic bluefin tuna (Thunnus thynnus). Res. Fish. Sci. 15:265-310.

Royer, F., Fromentin, J.M. and Gaspar, P. (2004) Association between bluefin tuna schools and oceanic features in the western Mediterranean. Mar. Ecol. Prog. Ser. 269:249-263.
Schaefer, K.M. (2001) Reproductive biology. In: Tunas: Physiology, Ecology and Evolution. B.A. Block \& E.D. Stevens (eds) San Diego: Academic Press, pp. 225-270.

Schroeder, W.W., Berner, L. Jr and Nowlin, W.D. Jr (1974) The oceanic waters of the Gulf of Mexico and Yucatan strait during July 1969. Bull. Mar. Sci. 24:1-19.

Scott, G.P., Turner, S.C., Grimes, C.B., Richards, W.J. and Brothers, E.B. (1993) Indices of larval bluefin tuna, Thunnus thynnus, abundance in the Gulf of Mexico: modeling variability in growth, mortality, and gear selectivity. Ichthyoplankton methods for estimating fish biomass. Bull. Mar. Sci. 53:912-929.

Sherrod, P.H. (2003) DTREG: Classification and regression trees for data mining and modeling. http://www.dtreg.com/ DTREG.pdf [accessed September 2009].

Sommer, U. and Stibor, H. (2002) Copepoda-Cladocera-Tunicata: the role of three major mesoplankton groups in pelagic food webs. Ecol. Res. 17:161-174.

Stokesbury, M.J.W., Teo, S.L.H., Seitz, A., O'Dor, R.K. and Block, B.A. (2004) Movement of Atlantic bluefin tuna (Thunnus thynnus) as determined by satellite tagging experiments initiated off New England. Can. J. Fish. Aquat. Sci. 61:1976-1987.

Stokesbury, M.J.W., Cosgrove, R., Boustany, A. et al. (2007) Results of satellite tagging of Atlantic bluefin tuna, Thunnus thynnus, off the coast of Ireland. Hydrobiologia 582:91-97.

Sturges, W. and Evans, J.C. (1983) On the variability of the loop current in the Gulf of Mexico. J. Mar. Res. 41:639-653.

Teo, S.L.H., Boustany, A.M. and Block, B.A. (2007a) Oceanographic preferences of Atlantic bluefin tuna Thunnus thynnus on their Gulf of Mexico breeding grounds. Mar. Biol. 152:1105-1119.

Teo, S.L.H., Boustany, A., Dewar, H. et al. (2007b) Annual migrations, diving behavior, and thermal biology of Atlantic bluefin tuna, Thunnus thynnus, on their Gulf of Mexico breeding grounds. Mar. Biol. 151:1-18.

Tserpes, G., Peristeraki, P. and Valavanis, V.D. (2008) Distribution of swordfish in the eastern Mediterranean, in relation to environmental factors and the species biology. Hydrobiologia 612:241-250.

Turner, R.E. and Rabalais, N.N. (1991) Changes in Mississippi river water quality this century: implications for coastal food webs. Bioscience 41:140-147.

Vayssieres, M.P., Plant, R.E. and Allen-Diaz, B.H. (2000) Classification trees: an alternative non-parametric approach for predicting species distributions. J. Veg. Sci. 11:679694.

Wilson, S.G., Lutcavage, M.E., Brill, R.W., Genovese, M.P., Cooper, A.B. and Everly, A.W. (2005) Movements of bluefin tuna (Thunnus thynnus) in the northwestern Atlantic Ocean recorded by pop-up satellite archival tags. Mar. Biol. 146:409-423.

Young, J.W. and Davis, T.L.O. (1990) Feeding ecology of larvae of southern bluefin, albacore and skipjack tunas (Pisces: Scombridae) in the eastern Indian Ocean. Mar. Ecol. Prog. Ser. 61:17-29.

Zavala-Hidalgo, J., Pares-Sierra, A. and Ochoa, J. (2002) Seasonal variability of the temperature and heat fluxes in the Gulf of Mexico. Atmosfera 15:81-104.

Zimmerman, R. and Biggs, D. (1999) Patterns of distribution of sound-scattering zooplankton in warm- and cold-core eddies in the Gulf of Mexico, from a narrowband acoustic Doppler current profiler survey. J. Geophys. Res. 104:5251-5262. 